\title{
Relationship between dietary antioxidant index (DAl) and antioxidants level in plasma of Kraków inhabitants
}

\author{
Emilia Kolarzyk ${ }^{1,4, A, C, F}$, Agata Pietrzycka ${ }^{2, B, E, F}$, Joanna Zając ${ }^{1, C, D, F}$, Joanna Morawiecka-Baranek ${ }^{3, C, F}$ \\ ${ }^{1}$ Department of Hygiene and Dietetics, Jagiellonian University Medical College, Kraków, Poland \\ ${ }^{2}$ Department of Pharmacobiology, Jagiellonian University Medical College, Kraków, Poland \\ ${ }^{3}$ The Regional Specialist Children's Hospital of St. Ludwig, Kraków, Poland \\ ${ }^{4}$ Cracow Higher School of Health Promotion, Kraków, Poland \\ A - research concept and design; $B$ - collection and/or assembly of data; $C$ - data analysis and interpretation; \\ $D$ - writing the article; $E$ - critical revision of the article; $F$ - final approval of article
}

\section{Address for correspondence \\ Emilia Kolarzyk}

E-mail:mykolarz@cyf-kr.edu.pl

\section{Funding sources}

None declared

\section{Conflict of interest}

None declared

Received on December 11, 2015

Revised on January 29, 2016

Accepted on February 17, 2016

\begin{abstract}
Background. Some literature data indicate that antioxidant-rich food may significantly increase antioxidants in serum and decrease the oxidative stress but results are ambiguous.

Objectives. The aim of this study was to estimate the total antioxidant capacity of food intake among the inhabitants of Kraków, Poland on the basis of dietary antioxidant index (DAl) and evaluation the relation between DAl and the level of antioxidants in plasma.
\end{abstract}

Material and methods. Examination included 70 (37 women and 33 men) non-smoking inhabitants of Krakow aged $46.4 \pm 13.7$ years. DAl was investigated on the basis of Food Frequency Questionnaire including 145 food items. DAl was measured using the method by Benzi and expressed as FRAP (mMol/L). In plasma samples total antioxidant status (TAS) expressed as FRAP and malondialdehyde (MDA) concentration as a marker of lipids peroxidation were measured.

Results. The mean value of DAl of all examined persons was $46.74 \pm 25.5 \mathrm{mMol} / \mathrm{L}$ (in female group: $54.13 \pm 27.7 \mathrm{mMol} / \mathrm{L}$; in male group: $37.83 \pm 19.5 \mathrm{mMol} / \mathrm{L} ; p<0.05)$. The highest contribution in total DWA value had fruits (48.7\%) opposite to vegetables (9.3\%). Statistically significant positive correlations between DAl and FRAP in plasma was found in all: $r=0.42$ and in female: $r=0.54$ groups (not significant in men group: $r=0.20$ ). Statistically significant negative correlation of DAl with MDA (malonylaldehyde) in female (-0.49) and male (-0.51) groups.

Conclusions. The obtained results confirmed the hypothesis that the intake of antioxidants in daily diet (measured as DAl) might increase antioxidants defense (measured by TAC as FRAP) and decrease oxidative stress (measured by MDA concentration in plasma). The dietary modification towards higher consumption of antioxidants (especially in men) should be highlighted in prevention of diseases in which oxidative stress play considerable role.

Key words: FRAP, MDA, healthy people, dietary antioxidant index, Food Frequency Questionnaire

DOI

$10.17219 /$ acem/61834

Copyright

Copyright by Author(s)

This is an article distributed under the terms of the

Creative Commons Attribution Non-Commercial License

(http://creativecommons.org/licenses/by-nc-nd/4.0/) 
The integrated antioxidant defense system plays the main role in the body's defense against reactive oxygen species (ROS) and oxidative stress. ${ }^{1}$ Antioxidants scavenge free radicals, ROS and reactive nitrogen species from cells, preventing or reducing the damage caused by the oxidation of body tissues. ${ }^{2}$ Free radicals can adversely alter lipids, proteins and DNA, and can trigger a number of human diseases. ${ }^{3}$ Oxidation leading to free radical formation can be accelerated by stress, smoking, alcohol intake, sunlight, air pollution and other factors. ${ }^{1}$ The antioxidant defense system includes the enzymatic system (e.g. superoxide dismutases $[\mathrm{Cu} / \mathrm{Zn}, \mathrm{Fe}$ and $\mathrm{Mn}$ types], catalase and glutathione peroxidase) and the non-enzymatic system (e.g. ascorbic acid, tocopherols, tocotrienols [vitamin E], copper, zinc and selenium). ${ }^{4-10}$ The main source of nonenzymatic antioxidants seems to be a well-balanced diet. Antioxidant activity and synergistic interactions between molecules in food and blood plasma are reflected by the total antioxidant capacity. In nutritional epidemiology, the dietary antioxidant index (DAI) is usually used to assess the intake of antioxidants from food. Evaluating the DAI is important because current literature data indicate that a diet enriched with multicomponent antioxidant foods like fruit, vegetables and vegetable oils, grains and cereal-based products, fresh herbs and certain beverages may significantly increase the concentration of antioxidants in plasma and therefore decrease oxidative stress. ${ }^{11}$

Many dietary antioxidants may contribute to cellular protection against radicals and other ROS. Many food products are rich sources of antioxidants. The main source of antioxidants in food are fruit and vegetables containing vitamins $\mathrm{C}$ and $\mathrm{E}$, selenium and carotenoids such as beta-carotene, lycopene, lutein and zeaxanthin. Vitamin E (8 structural isomers of tocopherols/tocotrienols) is one of the most widely distributed antioxidants in nature; $\alpha$-tocopherol is the best known and shows the most antioxidant activity. ${ }^{12}$ Vitamin E can to some degree prevent the consequences of oxidized LDL, and vitamin C provides nitric oxide synthase (NOS) activity. ${ }^{13}$ Good sources of specific antioxidants include anthocyanins in eggplant, grapes and berries; beta-carotene in pumpkin, mangoes, apricots, carrots, spinach and parsley; flavonoids in tea, green tea, citrus fruits, red wine, onions and apples; lycopene in tomatoes, pink grapefruit and watermelon; vitamin A in sweet potatoes, carrots, milk and egg yolks; vitamin $\mathrm{C}$ in black currants, kiwi fruit, mangoes, broccoli, spinach, peppers and strawberries; vitamin $\mathrm{E}$ in: vegetable oils (such as wheat germ oil), avocados, nuts, seeds and whole grains; zinc in seafood, lean meat, milk and nuts. Any of these may contribute significantly to the total DAI value. ${ }^{14}$

The aim of the study was to assess the daily intake of antioxidants among inhabitants of the Kraków metropolitan area on the basis of the DAI. Additionally, links between the DAI and the FRAP and MDA in plasma were examined.

\section{Material and methods}

Seventy healthy volunteers (37 women and 33 men) were enrolled in the study, which lasted for a period of 4 months (February to May, 2015). The participants were 21 to 73 years old (mean age: $46.4 \pm 13.7$ years). They were nonsmokers. They all provided written consent, and the study protocol was approved by the Bioethics Committee of the Jagiellonian University Medical College.

Each participants' dietary antioxidant index (DAI) was investigated on the basis of a food frequency questionnaire (FFQ). The questionnaire was prepared on the basis of American Dietetic Association recommendations. ${ }^{15}$ In the FFQ 145 food items were classified into groups such as fruit and dried fruit, vegetables and vegetable oils, sweets, grains and cereal-based products, mixed dishes, fresh herbs and spices and beverages. It was stated in the questionnaire that every nutritional position represents all forms of a particular food (fresh, frozen, dried, cooked or packed in cans) - e.g. "apples" means fresh apples, apple juice, compote, apple pie, etc.

The participants reported how often they had eaten each food in the previous month. In order to calculate the DAI for each participant, previously published databases from the USA and Italy, containing the most commonly consumed foods, were used. The size of a medium portion (100 g of a product, the volume of a glass, the content of a soup spoon or the amount of product necessary to spread over two pieces of bread, etc.) was included for every nutritional product in the questionnaire. Medium serving sizes were given as a reference; half of a medium portion was treated as a small portion, and one and a half or more of a medium portion was considered a large portion.

The total antioxidant capacity of the participants' food intake (their dietary antioxidant index) was measured using the method described by Benzie. ${ }^{16}$ This method exploits the ability of a given sample to reduce ferric ions to ferrous ions (FRAP), which are bound in a colored complex with tripyridyl-S-triazine. In the questionnaire the FRAP value of a medium portion of each product was included. The survey participants could declare small, medium or large portions. A small portion was counted as half of the FRAP value for a medium portion, and a large portion was counted as 1.5 times the FRAP value of a medium portion. The FRAP values specific for the size of the portion were multiplied by the number of portions and the total was divided by 30 days. This result was treated as the FRAP value of the daily nutritional intake (DAI).

DAI values for the male and female subgroups were compared using Student's t test.

Fasting blood samples were collected from the 70 participants once after a $12 \mathrm{~h}$ overnight fast. The blood samples were drawn into tubes containing K3 EDTA and were centrifuged within $4 \mathrm{~h}$ of collection from the participant. Plasma samples were collected and stored at $-30^{\circ} \mathrm{C}$ until the analyses of FRAP and MDA were done. 
Fig. 1. DAl values in the male and female study participants

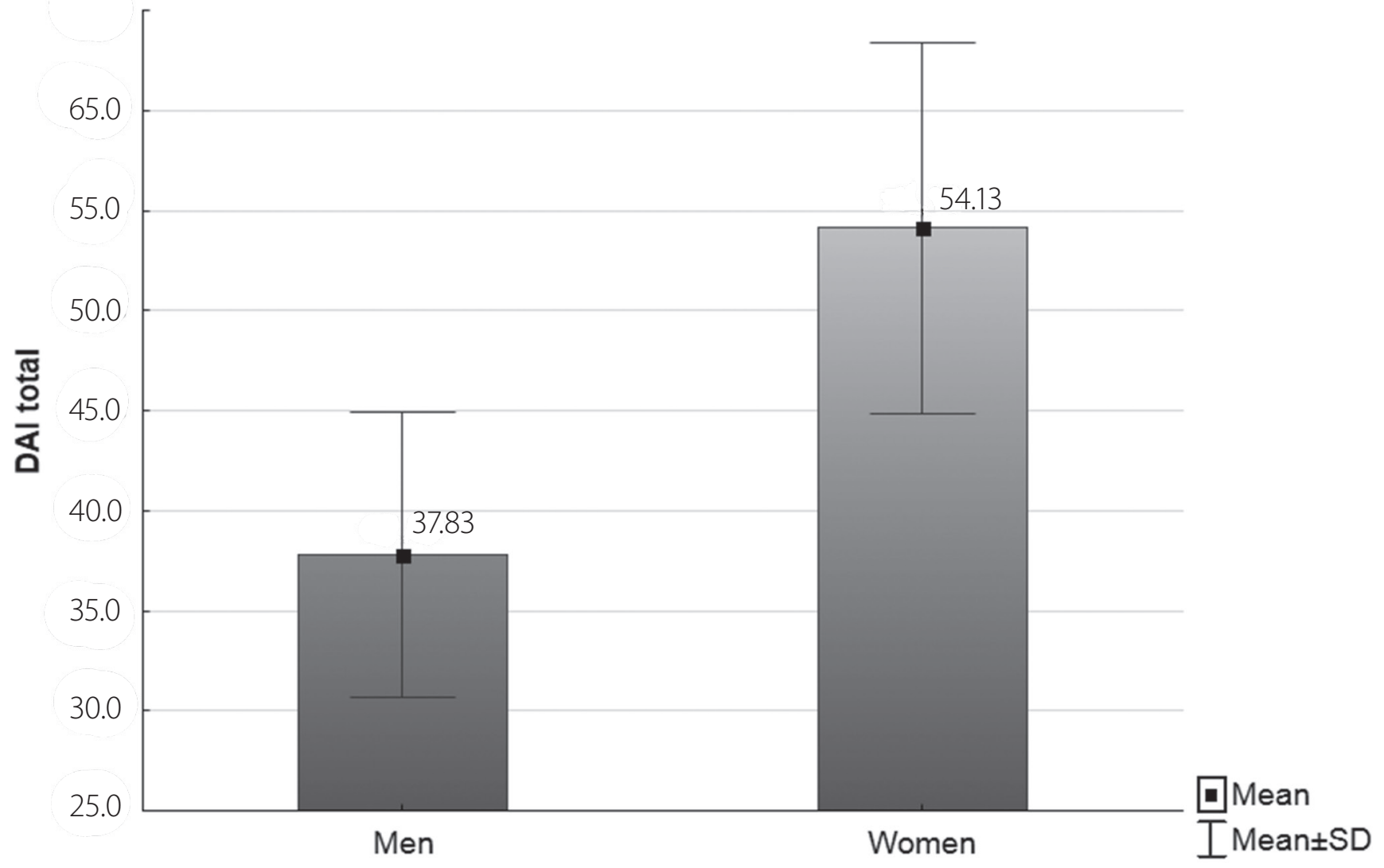

The total antioxidant status, expressed as FRAP, and malondialdehyde (MDA) concentration, as a marker of lipid peroxidation, were measured in the plasma samples. MDA was assayed by determining the coupling of MDA with thiobarbituric acid (TBA) under acid $\mathrm{pH}$ conditions at $95^{\circ} \mathrm{C}$. The TBA-MDA complex was determined fluorometrically at $532 \mathrm{~nm} .{ }^{17,18}$ MDA levels were expressed in $\mathrm{mMol} / \mathrm{L}$.

All the statistical analyses were carried out using STATISTICA for Windows software (v. 10.0, StatSoft Polska, Kraków, Poland). Differences were considered statistically significant if $\mathrm{p}<0.05$.

\section{Results}

The mean value of the DAI of the entire study group was $46.74 \pm 25.5 \mathrm{mMol} / \mathrm{L}$. The mean DAI value for the female participants $(54.13 \pm 27.7 \mathrm{mMol} / \mathrm{L})$ was statistically significantly higher $(\mathrm{p}<0.05)$ than the mean for the male participants $(37.83 \pm 19.5 \mathrm{mMol} / \mathrm{L})$.

The contribution of particular groups of food products, expressed as $\mathrm{mMol} / \mathrm{L}$ and as proportional contributions, in the entire study group and for the male and female subgroups are presented in Tables 1 and 2 .

In the entire study group as well as in the male and female subgroups, fruit contributed the most to the total
Table 1. The contribution of particular groups of food products in the total dietary antioxidant index (DAl) in the study group

\begin{tabular}{|c|c|c|c|}
\hline \multirow[t]{2}{*}{ Groups of food products } & $\begin{array}{c}\text { Men } \\
n=33\end{array}$ & $\begin{array}{l}\text { Women } \\
n=37\end{array}$ & $\begin{array}{c}\text { Total } \\
\mathrm{n}=70\end{array}$ \\
\hline & \multicolumn{3}{|c|}{$\mathrm{mMol} / \mathrm{L}$} \\
\hline Fruit and dried fruit & 20.52 & 24.69 & 22.70 \\
\hline Vegetables & $3.56^{*}$ & $4.92^{*}$ & 4.34 \\
\hline Fresh herbs and spices & 0.74 & 3.08 & 2.01 \\
\hline $\begin{array}{l}\text { Grains and cereal-based } \\
\text { products (pastas, rice) }\end{array}$ & $4.32^{*}$ & $7.96^{*}$ & 6.31 \\
\hline $\begin{array}{l}\text { Mixed dishes (traditional } \\
\text { Polish soups) }\end{array}$ & 0.78 & 0.89 & 0.84 \\
\hline Fish and seafood & 0.24 & 0.33 & 0.30 \\
\hline Fats and oils & 0.12 & 0.11 & 0.12 \\
\hline Sweets (chocolate, honey, jam) & 0.29 & 0.90 & 0.62 \\
\hline Beverages (coffee, tea, wine) & $7.26^{*}$ & $11.23^{*}$ & 9.43 \\
\hline $\mathrm{mMol} / \mathrm{L}$ & 37.83 & 54.13 & 46.74 \\
\hline
\end{tabular}

* statistically significant results. 
Table 2. The contribution percentages of particular groups of food products in the total dietary antioxidant index (DAI) in the study group

\begin{tabular}{|c|c|c|c|}
\hline \multirow{2}{*}{ Groups of food products } & $\begin{array}{l}\text { Men } \\
n=33\end{array}$ & $\begin{array}{l}\text { Women } \\
n=37\end{array}$ & $\begin{array}{l}\text { Total } \\
\mathrm{n}=70\end{array}$ \\
\hline & \multicolumn{3}{|c|}{$\mathrm{mMol} / \mathrm{L}$} \\
\hline Fruit and dried fruit & 54.22 & 45.62 & 48.72 \\
\hline Vegetables & 9.41 & 9.09 & 9.28 \\
\hline Fresh herbs and spices & 1.95 & 5.69 & 4.30 \\
\hline $\begin{array}{l}\text { Grains and cereal-based } \\
\text { products (pastas, rice) }\end{array}$ & 11.42 & 14.70 & 13.50 \\
\hline $\begin{array}{l}\text { Mixed dishes (traditional } \\
\text { Polish soups) }\end{array}$ & 2.06 & 1.65 & 1.80 \\
\hline Fish and seafood & 0.63 & 0.62 & 0.63 \\
\hline Fats and oils & 0.33 & 0.21 & 0.27 \\
\hline Sweets (chocolate, honey, jam) & 0.77 & 1.66 & 1.33 \\
\hline Beverages (coffee, tea, wine) & 19.19 & 20.76 & 20.17 \\
\hline$\%$ & 100 & 100 & 100 \\
\hline
\end{tabular}

Table 3. The concentration of FRAP $(\mathrm{mMol} / \mathrm{L})$ and MDA $(\mathrm{nMol} / \mathrm{mL})$ in the study group

\begin{tabular}{|l|c|c|c|c|c|c|}
\multicolumn{1}{c|}{$\begin{array}{c}\text { Men } \\
n=33\end{array}$} & \multicolumn{2}{c|}{$\begin{array}{c}\text { Women } \\
n=37\end{array}$} & \multicolumn{2}{c|}{$\begin{array}{c}\text { All } \\
n=70\end{array}$} \\
\hline & $\mathrm{X}$ & $\mathrm{SD}$ & $\mathrm{X}$ & $\mathrm{SD}$ & $\mathrm{x}$ & $\mathrm{SD}$ \\
\hline FRAP mMol/L & 1.07 & 0.42 & 1.19 & 0.44 & 1.14 & 0.43 \\
\hline MDA $\mathrm{nMol} / \mathrm{mL}$ & 9.12 & 7.75 & 10.14 & 7.60 & 9.66 & 7.16 \\
\hline
\end{tabular}

Table 4. The values of correlation coefficients among the male and female study participants

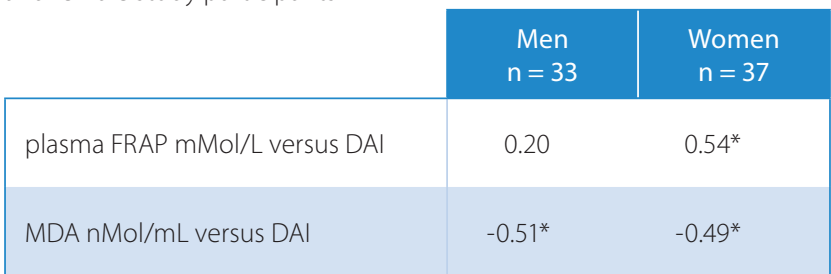

${ }^{*}$ statistically significant results.

dietary antioxidant index (48.7\% in the full group). Beverages, especially coffee, were in the second position $(20.2 \%$ in the whole study group), and next were grains and cerealbased products (13.5\% in the full group). Vegetables were eaten very rarely (only $9.3 \%$ of the total DAI value in the entire group). The contributions of the remaining food products (fresh herbs and spices, fish and seafood, fats and oils, mixed dishes and sweets were low: $8.3 \%$ in the entire study group).
It was found that there were statistically significant differences between men and women in the DAI values for vegetables, grains and cereal-based products and beverages (Fig. 2).

The plasma total antioxidant ability, expressed as FRAP, and plasma MDA levels are presented in Table 3.

In the entire study group as well as in the male and female subgroups, a statistically significant correlation was found between the mean DAI value and FRAP in plasma $(r=0.42)$. A negative correlation was found in all 3 groups between the mean DAI value and plasma MDA level $(\mathrm{r}=-0.45)$ (Fig. 3).

The correlation coefficient between FRAP in plasma and the DAI was statistically significant only among the female participants $(r=0.54)$. In male subgroup this coefficient did not reach statistical significance $(r=0.20)$. The correlation coefficients between the DAI and MDA in plasma were statistically significant in both the male and female subgroups (Table 4).

\section{Discussion}

According to the Food-Based Dietary Guidelines created by the National Nutrition Institute in Warszawa and the Polish Ministry of Health, a healthy diet should include fruit and vegetables in amounts equal at least half of the daily food intake, with a $3: 1$ proportion of vegetables to fruit. The amount of fats should be low, and where possible substituted with vegetables oils or soft margarines. ${ }^{19}$ The results of this study showed that vegetables were eaten too rarely and their contribution to the total DAI value was too low. Fruit contributed the most to the total DAI values. As in the present study, other authors have found that among both healthy and ill subjects the main source of natural antioxidants in the daily diet is fruit. ${ }^{20}$ For many people in Poland fruit is bought and consumed mainly during the summer. Plasma antioxidant capacity was lower in autumn and in winter, compared to relatively the high level during the summer; the lowest was noted in spring. ${ }^{21}$ This discrepancy is caused by higher consumption of fruit (e.g. strawberries, raspberries, cherries, gooseberries, currants) and seasonal vegetables (young beet leaves, kohlrabi, asparagus, sorrel, green beans, zucchini). Moreover, it should be noted that the antioxidant potential of fruits and vegetables during winter is lowered because of transportation and long periods of storage. Therefore the recommendation for Polish people should be to increase consumption of fruit and vegetables from local producers (e.g. cultivated in greenhouses) during the spring, autumn and winter. In addition, consumption of citrus fruit, fruit/vegetable drinks and spices can be suggested to fill shortages in antioxidative potential when fresh seasonal products are not available.

Currently, specialists in nutrition consider dietary enrichment with functional foods and supplements a very 
Fig. 2. The statistically significant differences in DAl (Student's t-test) of consumed vegetables, grain and cereal based products and beverages between female and male groups
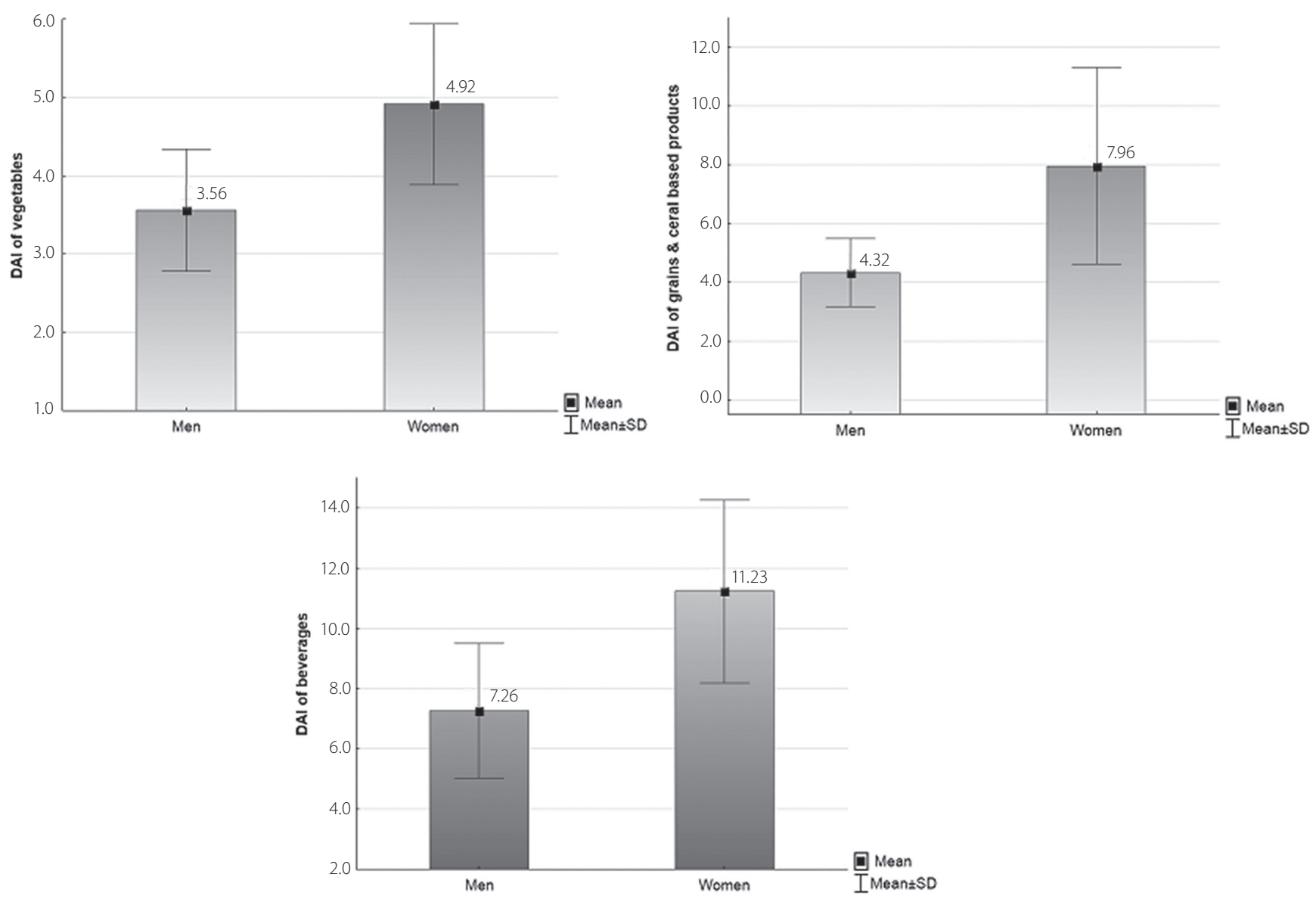

Fig. 3. The values of correlation coefficients in all examined groups

FRAP VERSUS DAI total:
$r=0.42 ; p=0.001$
MDA versus DAl total:
$r=-0.45 ; p=0.001$
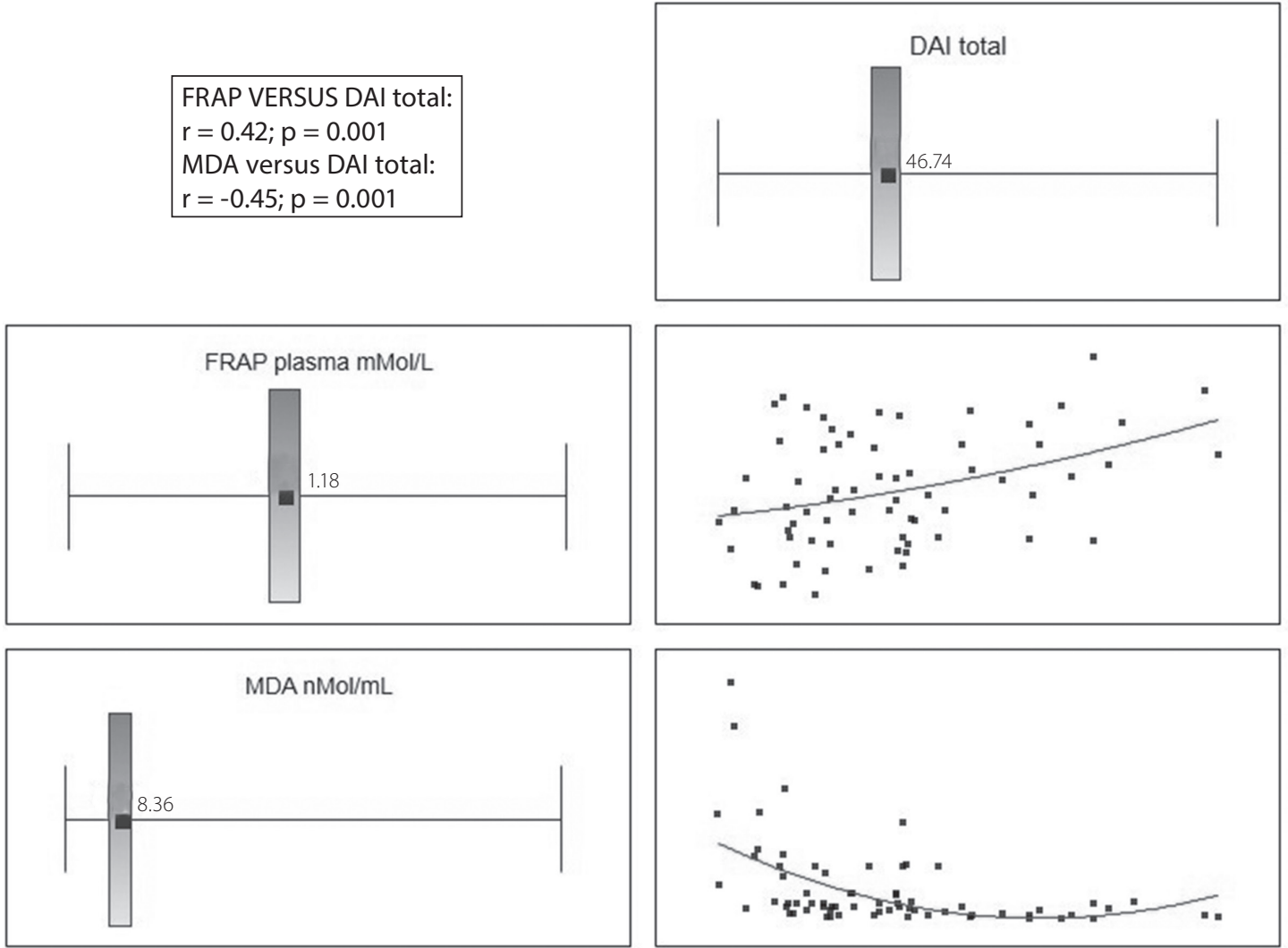
important factor in the prevention of degenerative disorders caused by oxidative stress. $^{22}$ Unfortunately, the results of large studies are not optimistic. ${ }^{23}$ Some recent studies - the Women's Antioxidant Cardiovascular Study (8,000 female health professionals, aged 40 years or older), the Women's Health Study (40,000 healthy women at least 45 years old) and the selenium and vitamin E Cancer Prevention Trial (SELECT; 35,000 men aged 50 or older) - showed that antioxidant supplements did not help prevent diseases caused by oxidative stress. ${ }^{24-26}$ The evidence suggests that antioxidant supplements do not work as well as the naturally occurring antioxidants in food. Moreover, taking supplements in high doses can be harmful. Dietary supplements may cause side effects, trigger allergic reactions or interact with prescription and over-the-counter medicines. ${ }^{23,27}$ Therefore, a healthy diet remains the best way to provide sufficient antioxidant intake. Many researchers have shown that sufficient consumption of fruit and vegetables is associated with a reduced rate of some diseases (especially coronary heart disease) and with a lower risk of all-cause mortality - particularly cardiovascular mortality, but also cancer mortality. ${ }^{28,29}$

It is worth pointing out that it is not clear whether these results are related only to the amount of antioxidants in vegetables and fruit, or to other components of these products, or to lifestyle factors such as stress, air pollution, etc. People who eat more antioxidant-rich food might also be more likely to be physically active and less likely to smoke, and it is clear that physical exercise and not smoking are crucial in the prevention of cardiovascular diseases, stroke, intestinal cancer, etc. All these factors may decrease the risk of disease, but the results of the present study confirmed a direct link between the DAI and the level of TAS and lipid peroxidation markers in plasma, indicating that a diet rich in antioxidant foods should also decrease the risk of oxidative stress disorders. It is also important to emphasize that the positive correlation between the DAI and plasma MDA in both the male and female subgroups suggests that a diet rich in antioxidants may reduce the risk of developing various pathological conditions, such as MDA-induced cell injury via, as Ayala et al. wrote, "intramolecular or intermolecular protein/DNA crosslinking that may induce profound alteration in the biochemical properties of biomolecules". ${ }^{30}$ Unfortunately the present study found no correlation between DAI and the total antioxidant status of plasma expressed as FRAP in men, which may be partially explained by the lower intake of antioxidants in their diet (in comparison to women).

\section{Conclusions}

The results of the study confirmed the hypothesis that the intake of antioxidants in the daily diet might increase antioxidant defense (measured by the total antioxidant status of plasma expressed as FRAP) and decrease oxidative stress (measured by plasma MDA concentration). Introducing an anti-oxidant diet should therefore become an interesting approach to the prevention of disorders caused by increased oxidative stress.

Dietary modification towards higher consumption of natural antioxidants (especially by men) should be implemented as a public health strategy.

\section{References}

1. Lobo V, Patil A, Phatak A, Chandra N. Free radicals, antioxidants and functional foods: Impact on human health. Pharmacogn Rev. 2010;4:118-126.

2. Kalam S, Gul MZ, Singh R, Ankati S. Free radicals: Implications in etiology of chronic diseases and their amelioration through nutraceuticals. Pharmacologia. 2015;6:11-20.

3. El-Beltagi HS, Mohamed HI. Reactive oxygen species, lipid peroxidation and antioxidative defense mechanism. Not Bot Horti Agrobo. 2013;41:44-57.

4. Zelko I, Mariani T, Folz R. Superoxide dismutase multigene family: A comparison of the CuZn-SOD (SOD1), Mn-SOD (SOD2), and ECSOD (SOD3) gene structures, evolution, and expression. Free Radic Biol Med. 2002;33:337-349.

5. Johnson F, Giulivi C. Superoxide dismutases and their impact upon human health. Mol Aspects Med. 2005;26:340-352.

6. Chelikani P, Fita I, Loewen PC. Diversity of structures and properties among catalases. Cell Mol Life Sci. 2004;61:192-208.

7. Hayes J, Flanagan J, Jowsey I. Glutathione transferases. Ann Rev Pharmacol Toxicol. 2005;45:51-88.

8. Padayatty S, Katz A, Wang Y, Eck P, Kwon O, Lee J. Vitamin C as an antioxidant: Evaluation of its role in disease prevention. J Am Coll Nutr. 2003;22:18-35.

9. Clarke MW, Burnett JR, Croft KD. Vitamin E in human health and disease. Crit Rev Clin Lab Sci. 2008;45:417-450.

10. Tinggi U. Selenium. Its role as antioxidant in human health. Environ Health Prev Med. 2008;13:102-108.

11. Zilica SC, Zita VH, Sukalovic S, et al. Anti-oxidant activity of small grain cereals caused by phenolics and lipid soluble antioxi-dants. J Cereal Sci. 2011;54:417-424.

12. Linares $E$, Thimonier $C$, Degre $M$. The effect of neopuntia(r) on blood lipid parameters-risk factors for the metabolic syndrome (syndrome x). Adv Ther. 2007;24:1115-1125.

13. Ozkanlar S, Akcay F. Antioxidant vitamins in atherosclerosis-animal experiments and clinical studies. Adv Clin Exp Med. 2012;21:115-123.

14. Landete JM. Dietary intake of natural antioxidants: Vitamins and polyphenols. Crit Rev Food Sci Nutr. 2013;53:706-721.

15. Satia JA, Watters JL, Galanko JA. Validation of an antioxidant nutrient questionnaire in Whites and African Americans. J Am Diet Assoc. 2009;109;502-508.

16. Benzie IF, Strain JJ. The ferric reducing ability of plasma (FRAP) as a measure of "antioxidant power": The FRAP assay. Anal Biochem. 1996;239:70-76.

17. Esterbauer $\mathrm{H}$, Cheeseman $\mathrm{KH}$. Determination of aldehydic lipid peroxidation products: Malonaldehyde and 4-hydroxynonenal. Methods Enzymol. 1990;186:407-421.

18. Wasowicz W, Neve J, Peretz A. Optimized steps in fluorometric determination of thiobarbituric acid-reactive substances in serum: Importance of extraction $\mathrm{pH}$ and influence of sample preservation and storage. Clin Chem. 1993;39:2522-2526.

19. http://www.izz.waw.pl

20. WawrzyniakA, Krotki M, Stoparczyk B. Właściwościantyoksydacyjne owoców i warzyw. Med Rodz. 2011;1:19-23.

21. Człapka-Matysik, Kostrzewa-Tarnowska A, Bajerska J. Potencjał antyoksydacyjny racji pokarmowych pacjentów ze zdiagnozowanymi chorobami układu krążenia. Zyw Nauka Technol Jakosc. 2009;4:312-319.

22. Butnariu M, Caunii A. Design management of functional foods for quality of life improvement. AAEM. 2013;20:736-741. 
23. Chun OK, Floegel A, Chung SJ, Chung CE, Song WO, Koo S. Estimation of antioxidant intakes from diet and supplements in U.S adults. J Nutr. 2010;140:317-324.

24. Cook NR, Albert CM, Gaziano JM, et al. A randomized factorial trial of vitamins $C$ and $E$ and beta carotene in the secondary prevention of cardiovascular events in women: Results from the women's antioxidant cardiovascular study. Arch Intern Med. 2007;167:1610-1618.

25. Lee IM, Cook NR, Gaziano JM, et al. Vitamin E in the primary prevention of cardiovascular disease and cancer: The women's health study: A randomized controlled trial. JAMA. 2005;294:56-65.

26. Klein EA, Thompson IM Jr, Tangen CM, et al. Vitamin E and the risk of prostate cancer: The selenium and vitamin $\mathrm{E}$ cancer prevention trial (SELECT). JAMA. 2011;306:1549-1556.
27. Jerome-Morais A, Diamond AM, Wright ME. Dietary supplements and human health: For better or for worse? Mol Nutr Food Res. 2011;55:122-135.

28. Joshipura KJ, Hu FB, Manson JE, et al. The effect of fruit and vegetable intake on risk for coronary heart disease. J Nutr. 2006;136:2588-2593.

29. Wang X, Ouyang Y, Liu J, et al. Fruit and vegetable consumption and mortality from all causes, cardiovascular disease, and cancer: Systematic review and dose-response meta-analysis of prospective Cohort studies. BMJ. 2014;349:94490.

30. Ayala A, Muñoz MF, Argüelles S. Lipid peroxidation: production, metabolism, and signaling mechanisms of malondialdehyde and 4-hydroxy-2-nonenal. Oxid Med Cell Longev. 2014:360438. doi: 10.1155/2014/360438. Epub 2014 May 8. 